\title{
Cyanobacterial and algal abundance and biomass in cave biofilms and relation to environmental and biofilm parameters
}

\author{
Slađana Popović ${ }^{1}$, Nataša Nikolić ${ }^{2}$, Jelena Jovanovićc ${ }^{3}$, Dragana Predojević ${ }^{2}$, \\ Ivana Trbojević ${ }^{2}$, Ljiljana Manić ${ }^{2}$, and Gordana Subakov Simić ${ }^{2}$ \\ ${ }^{1}$ University of Belgrade, Scientific Institution, Institute of Chemistry, Technology and Metallurgy, National Institute, Center for Ecology and \\ Technoeconomics, Njegoševa 12, 11000 Belgrade, Serbia \\ ${ }^{2}$ University of Belgrade, Faculty of Biology, Institute of Botany and Botanical Garden "Jevremovac", Takovska 43, 11000 Belgrad, Serbia \\ ${ }^{3}$ Institute of Public Health of Serbia Dr Milan Jovanovic Batut, Dr Subotića 5, 11000 Belgrade, Serbia
}

\begin{abstract}
Due to life in extreme environments, cyanobacteria and algae from cave biofilms that form at the entrances or deep inside the cave around artificial lights are of increasing interest to many scientists. It is well-known that many phototrophic microorganisms are first to colonize exposed substrata and produce the organic matter on which other biofilm constituents relly. Many studies dealing with phototrophic microorganisms from biofilms focus on the diversity and community composition of cyanobacteria and algae, while quantitative assessments are rarely implemented. Biofilm sampling was conducted in Degurić and Vernjikica Cave located in Western and Eastern Serbia, respectively. Ecological parameters (temperature, relative humidity, light intensity) and distance from the entrance were measured. Additionally, chlorophyll content, as well as biofilm parameters (water content, organic and inorganic matter) were determined. The abundance of phototrophic microorganisms was assessed on microscope slides which contained $1 \mathrm{mg}$ of biofilm that was dehydrated for a short period of time and homogenized prior to slide preparation, and then rehydratated. The biomass of recorded cyanobacterial and algal taxa was calculated by applying geometric approximations and standard mathematical formulas. In Degurić Cave, at the sampling site where the highest biomass was documented, the higher diversity, water content and chlorophyll values were also recorded, while in Vernjikica Cave a high content of organic matter was documented. According to the multivariate analyses performed, the biomass of simple trichal Cyanobacteria, Bacillariophyta, and Xanthophyta was positively correlated with the content of organic matter in biofilm and light intensity, while coccoid and heterocytous Cyanobacteria and Chlorophyta showed a positive correlation with water content in the biofilm, relative humidity and distance from the entrance. The total biomass was positively correlated with the chlorophyll content, organic matter and light intensity, and negatively with the distance from the entrance.
\end{abstract}

Keywords: $\quad$ cyanobacteria, biofilm, quantitative assessment, abundance and biomass, algae

Received 5 August 2018; Revised 8 February 2019; Accepted 13 February 2019

Citation: Popović S., Nikolić N., Jovanović J., Predojević D., Trbojević I., Manić Lj. and Subakov Simić G., 2019. Cyanobacterial and algal abundance and biomass in cave biofilms and relation to environmental and biofilm parameters. International Journal of Speleology, 48 (1), 49-61. Tampa, FL (USA) ISSN 0392-6672 https://doi.org/10.5038/1827-806X.48.1.2224

\section{INTRODUCTION}

Biofilms that develop on surfaces exposed to air consist of different microorganisms, among which are aerophytic cyanobacteria and algae. This interesting group of microorganisms is nowadays studied worldwide (Albertano, 2012). Those inhabiting caves, as one of the extreme environments, are of special interest and thus studied from different aspects, due to their specificity, ecology and physiology, form of the adaptation to the extreme environment, the potential discovery of new taxa, lampenflora management, etc. This refers both to taxa that live at the cave entrances and deep inside the cave, at places surrounding artificial lights (i.e. Rajczy, 1986; Abdelahad, 1989; Sant'Anna et al., 1991; Garbacki et al., 1999; Pentecost \& Zhaohio, 2001; Pouliĉkova \& Hašler, 2007; Selvi \& Altuner, 2007; Smith \& Olson, 2007; Lamprinou et al., 2009; Vinogradova et al., 2009; Martinez \& Asencio, 2010; Mulec et al., 2012; Borderie et al., 2014; Sallstedt et al., 2014; Tofilovska et al., 2014; Czerwik-Marcinkowska et al., 
2015; Popović et al., 2015a, b; 2016a, b, c; Pflender et al., 2017; Popović et al., 2017a, b; Pflender et al., 2018a, b;). Numerous studies focus on the diversity of taxa in caves or the qualitative analysis of biofilm samples which give us information about community composition. Nevertheless, quantitative analyses of phototrophic biofilms exposed to air aren't oftenly represented in scientific research.

The quantitative assessment of cyanobacteria and algae - the study of their abundance and biomass, is a quite common tool in monitoring of different water bodies. It is frequently used in the assessment of water quality and ecological status of rivers and lakes. However, the quantification of these parameters in biofilm that is exposed to air is quite rare, in general. The counting of cyanobacterial and algal cells on opaque surfaces can be, e.g., carried out directly by using the epifluorescence microscope (Welton et al., 2005), which is a fast and non-destructive method based on chlorophyll fluorescence. The abundance of microorganisms can also be assessed using certain scales (based on the frequency in which they appear in the sample). Some scales for the assessment of relative abundance of organisms in water samples are represented in Breitig and Tümpling (1982) and European standard for water quality (BS EN 15708:2009). Following this approach, we tried to use a scale from 1 to 5 in the study Popovic et al. (2015a). Using this approach, we cannot precisely determine the share of each taxon in the community. Some researchers reported the use of different sedimentation chambers (often used in phytoplankton analyses) for determining the cyanobacterial and algal abundance in biofilm samples. The preparation of biofilm for sedimentation implies proper biofilm sampling from the substrate, homogenization in water, followed by sedimentation and counting of cyanobacterial and algal cells (Welton et al., 2005). One of the novel approaches that is easy-to-use and represents a fast method for biofilm characterization (qualitative and quantitative) and detection of biofilm community structure changes is flow cytometry. This method is mostly used for biofilms that originate from water ecosystems, for pro- and eukaryotic microorganism cells (Sgier et al., 2016; Wilson et al., 2017). However, there are also some attempts at studying the aerophytic biofilms: Borderie et al. (2016) investigated the microbial composition of biofilms proliferating in a show cave (both heterotrophic prokaryotes and autotrophic microorganisms) using this approach.

The aim of this study was to quantitatively assess cyanobacteria and algae in biofilm samples, i.e. to determine the abundance and biomass of cyanobacteria and algae from cave biofilms, as well as to relate biomass to environmental and biofilm parameters. For abundance and biomass determination, microscope slides containing biofilm of known mass, that was shortly dehydrated and homogenized prior to slide preparation, and then rehydrated, were made.

\section{MATERIALS AND METHODS}

\section{Sampling sites}

The Degurić Cave (Fig. 1a) is located in Western Serbia, in the municipality of Valjevo, on the right side of the Gradac River, $216 \mathrm{~m}$ above the sea level. This is an active spring cave with a continuous flow of the Degurićka River (Đurović, 1998). Speleologists are still exploring this cave and according to the latest data that revealed the presence of many side channels, as well as five siphons, this is the longest cave of the Lelić karst (Milanović, 2012). The entrance is $5 \mathrm{~m}$ wide and $3 \mathrm{~m}$ high (Petrović, 1976) and the main channel is uniform from the beginning to the end of the cave. The cave is poor in cave formations, bearing in mind that only few groups of stalactites and stalagmites are observed (Đurović, 1998).

Vernjikica Cave (Fig. 1b, c) is located on the left side of the Lazareva River canyon, in the municipality of Bor, about $5 \mathrm{~km}$ from the village Zlot. The upper entrance is located at an altitude of $454 \mathrm{~m}$, about $150 \mathrm{~m}$ above the Lazareva River. The length of the explored channels is $1015 \mathrm{~m}$. The cave consists of one descending cascade channel that connects several halls, with the circular hall of 50-60 $\mathrm{m}$ in diameter and the largest height reaching $50 \mathrm{~m}$. This is a typical dry cave formed in dry limestones which influenced the formation of diverse cave structures that decorate the halls: stalactites, stalagmites, pillars and draperies (Petrović, 1976; Đurović, 1998; Milanović, 2012).

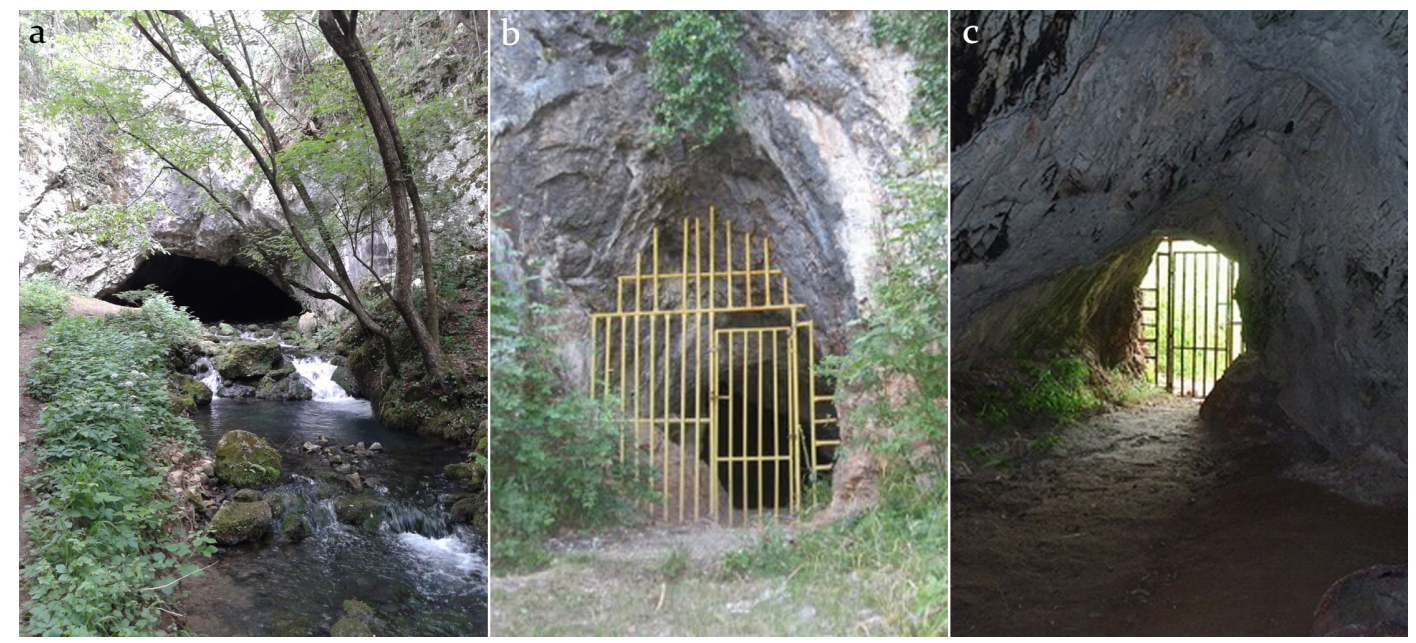

Fig. 1. Degurić Cave (a) and Vernjikica Cave (b and c). 


\section{Environmental parameters}

Prior to biofilm sampling, the measurement of ecological parameters was performed. Temperature, relative humidity and light intensity, were measured three times at each sampling site using the Temperature Humidity Meter, Extech, USA and DMV 1300 Luxmeter, Velleman, Belgium.

\section{Biofilm sampling}

Five sampling sites with different biofilm (different color and appearance, i.e., gelatinous, dry, powdered, etc.) were chosen for sampling in Degurić Cave, as well as in Vernjikica Cave. All sampling sites were located at the cave wall on vertical surfaces (left or right from the cave entrance). The distance of every sampling site from the cave entrance was measured and expressed in meters. In order to provide adequate qualitative and quantitative data, two methods of biofilm sampling were applied: non-destructive adhesive-tape method (Gaylarde \& Gaylarde, 1998; Urzi \& de Leo, 2001) and scraping biofilm directly from the stone substrata using flame-sterilized scalpel (Popović et al., 2015a; 2017a). As proposed in studies by Gaylarde \& Gaylarde (1998); Urzì \& de Leo (2001), and described in Popović et al. (2015a), tape strips were put and gently pressed to the stone surfaces with biofilm, then removed and placed on microscope slides. Adhesive tape strips with biofilm content were fixed with a drop of glycerol and stored in microscope slide boxes, while biofilm samples were transported to the laboratory in labeled sterile polyethylene bags. For the determination of chlorophyll (Chl) content, water content and content of inorganic/organic matter in biofilm samples it was necessary to take biofilm samples from exactly known surface. For that purpose, a round metal matrix covering a surface of $3.14 \mathrm{~cm}^{2}$ was used as described in Popović et al. (2017a). The round metal matrix is carefully pressed on the stone surface (if it is possible flat one) and turned clockwise or counterclockwise to mark the area from which the biofilm will be sampled. Biofilm is sampled using scalpel and placed in a sterile polyethylene bags to be transported to the laboratory.

\section{Determination of $\mathrm{Ch} \mathbf{l}$ and biofilm content}

The concentration of Chl was determined based on the modified phytoplankton formula and standard ISO 10260: 1992, as described in Popović et al. (2015a) and expressed as $\mu \mathrm{g} \mathrm{Chl} \mathrm{cm}{ }^{-2}$. Since for chlorophyll extraction ethanol, acetone and methanol can be used, Pápista et al. (2002) re-examined the ISO 10260: 1992 and compared the extraction yields of these three solvents and concluded that extraction with methanol provide both the highest extraction yield and the lowest standard error value. However, due to the toxicity of methanol, this solvent is not widely used, and instead, ethanol is adopted as a safe alternative (Nagarkar \& Williams, 1997). Water content and content of inorganic/organic matter in biofilm samples were determined following the procedure described in Popović et al. (2017a).

\section{Quantitative algological analyses}

Prior to the quantitative analysis, qualitative analysis of phototrophic microorganisms from biofilm samples was performed using light microscope Zeiss Axio-Imager M.1 with software AxioVision 4.8. The adhesive strips were directly observed. Considering biofilm samples, permanent microscope slides in triplicate were made using the sample mixed with glycerol. Cyanobacteria and algae were identified using the standard literature: Krieger \& Gerloff (1962), Starmach (1972), Komárek \& Fott (1983), Komárek \& Anagnostidis (1998), John et al. (2003), Komárek \& Anagnostidis (2005), Hofmann et al. (2013) and Komárek (2013).

Since there is no precisely defined method that is adequate for the assessment of the abundance of aerophytic cyanobacteria and algae in aerophytic biofilm samples, the quantitative analysis was performed using microscope slides prepared as described bellow. For the preparation of these slides, well-homogenized biofilm was needed. In order to make homogenization easier, part of each biofilm sample was first dried at $105^{\circ} \mathrm{C}$ for 1 minute, after which it was carefully homogenized using a glass stick. Subsequently, $0.001 \mathrm{~g}$ (1 mg) of each dry biofilm sample was measured using the analytical scale and placed on a microscope slide. The biofilm was first mixed with a drop of water to be rehydrated, then carefully and equally mixed with a drop of glycerine, after which cover glass was put over it and fixed with nail polish.

The counting of cyanobacteria and algae was performed in randomly selected transects on microscope slides using magnification of $400 x$ or 630x. One transect (arrows on Fig. 2) along which the counting was performed, represented the path from the left edge of the cover glass (marked as "d" on Fig. 2) to the right edge or vice versa. According to the upper scale (marked as "b" on Fig. 2) on the microscope stand (Fig. 2), one transect accounted for 20 sections. We first randomly chose a place on the microscope slide from which to start the count (usually from left to the right) and marked on which line the upper scale is. By moving the microscope slide, part of the scale marked as "a" also moves enabling us to see how much scale lines we have passed. We have counted until we reached 500 individuals in each biofilm sample. During the counting, we would either pass only a part of the selected transect (corresponding to the certain number of lines on the upper scale), or more transects, depending on the sample. One cover glass may have a different number of transects depending on the magnification used. If we passed only a part of the transect, we first calculate how many individuals and cells of phototrophic microorganisms there are in one transect, according to the upper scale. This number is then multiplied with the number of transects to obtain how many individuals and cells are beneath the whole cover glass or in the weight of $0.001 \mathrm{~g}$ of biofilm.

Biomass was calculated taking into account the dimensions and abundance of each taxon. First, each taxon was assigned a certain geometric body, considering that cells can have the form of simple geometric bodies, or complex shapes that are built from several simple shapes. Geometric bodies that were observed in our study were sphaere, halfsphaere, 


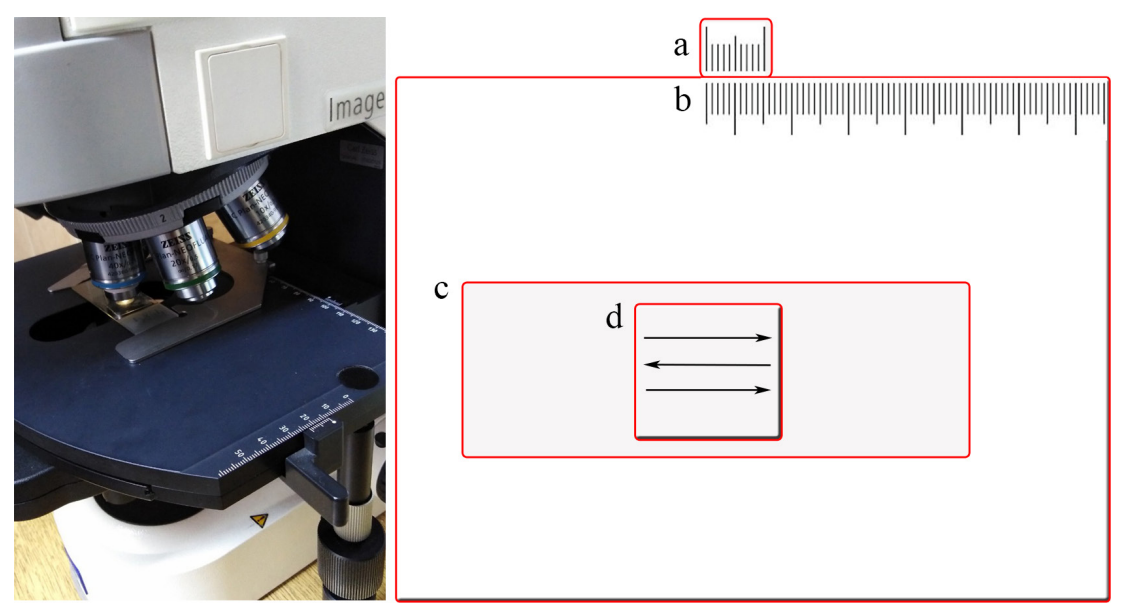

Fig. 2. The illustration that explains counting of cyanobacteria and algae and calculating the number of these microorganisms beneath the cover glass (in the known biofilm weight). a) the scale that moves when microscope slide moves; b) the upper scale on the microscope stand; c) microscope slide; d) cover glass; arrows - transects along the counting was performed.

ellipsoid, half of the elliptical prism, roller and cuboid. The biomass for each taxon was determined using geometric approximations and standard mathematical formulas according to Hillebrand et al. (1999) and Sun \& Liu (2003).

Dimensions of the cells are measured taking into account 25 individuals of the same taxon from each sample, and the average value was used in mathematical formulas. Biomass of each taxon was used to calculate the total biomass of cyanobacteria and algae within the biofilm sample:

$$
\text { Vtotal }=\Sigma(\mathrm{N} \times \mathrm{V})
$$

Vtotal - the total biomass of cyanobacteria and algae in biofilm sample $\left(\mu \mathrm{m}^{3} / \mathrm{mg}\right)$;

$\mathrm{N}$ - number of cells of a certain taxon in $1 \mathrm{mg}(0.001 \mathrm{~g})$ biofilm sample;

$\mathrm{V}$ - average volume of a certain taxon cell $\left(\mathrm{\mu m}^{3} / \mathrm{mg}\right)$.

The final biomass value is expressed in $\mu \mathrm{m}^{3} / \mathrm{mg}$ (for phytoplankton $\mu^{3} / \mathrm{L}$ ). Assuming that the cell density is 1 , values of the phytoplankton biomass are expressed in $\mu \mathrm{g} / \mathrm{L}$, using the following conversion: $\mu^{3} / \mathrm{L}=10^{-6} \mu \mathrm{g} / \mathrm{L}$. According to this, the final biomass of cyanobacteria and algae in the biofilm samples is expressed in $\mu \mathrm{g} / \mathrm{mg}$.

\section{Statistical analyses}

Principal component analysis (PCA) and detrended correspondence analysis (DCA) analyses were performed to illustrate the relationship of quantitative parameters - abundance and biomass, with following ecological and biofilm parameters: temperature $(\mathrm{T})$, relative humidity $(\mathrm{RH})$, light intensity (LI), water content in biofilm (WC), the content of organic matter (OM), the content of inorganic matter (IM), the distance from the entrance and the concentration of Chl. PCA represents the relationship of the mentioned ecological and biofilm parameters and the total biomass, number of cells and individuals, while DCA focus on the relationship between the same parameters and the biomass of every algal and cyanobacterial group separately. Software Canoco for Windows, version 5, was used (Ter Braak \& Šmilauer, 2012).

\section{RESULTS}

The values of measured ecological parameters are presented in Table 1, as well as the data referring to the distance of the sampling site from the entrance of caves expressed in meters. Temperature did not vary a lot between sampling sites in Degurić Cave, but in Vernjikica Cave, sampling site V4 and V5 had $4^{\circ} \mathrm{C}$ higher temperature from the rest. Relative air humidity also did not show big variations. It is worth mentioning that the highest value in Degurić Cave was recorded at sampling site D5, and in Vernjikica Cave at V1. Light intensity showed the highest variation in both caves.

Table 1. The values of measured ecological parameters (T: temperature, $\mathrm{RH}$ : relative humidity, LI: light intensity), and distance from the cave entrance. D1-D5: sampling sites in Deguric Cave; V1-V5: sampling sites in Vernjikica Cave.

\begin{tabular}{|c|c|c|c|c|c|}
\hline & Sampling site & $\mathbf{T}\left({ }^{\circ} \mathbf{C}\right)$ & RH (\%) & LI (Lux) & Distance (m) \\
\hline \multirow{5}{*}{ 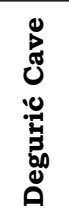 } & $\mathrm{D} 1$ & $22.4 \pm 0.11$ & $62.0 \pm 3.0$ & $108 \pm 9$ & 3.0 \\
\hline & $\mathrm{D} 2$ & $20.8 \pm 0.10$ & $63.0 \pm 2.0$ & $250 \pm 8$ & 3.5 \\
\hline & D3 & $20.4 \pm 0.10$ & $69.0 \pm 2.0$ & $140 \pm 6$ & 4.5 \\
\hline & D4 & $20.0 \pm 0.05$ & $67.0 \pm 3.0$ & $111 \pm 7$ & 5.0 \\
\hline & D5 & $19.7 \pm 0.08$ & $82.0 \pm 1.0$ & $241 \pm 5$ & 1.0 \\
\hline \multirow{5}{*}{ 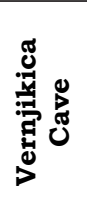 } & V1 & $17.1 \pm 0.10$ & $68.0 \pm 1.0$ & $67 \pm 4$ & 2.0 \\
\hline & $\mathrm{V} 2$ & $17.3 \pm 0.10$ & $65.0 \pm 2.0$ & $210 \pm 7$ & 2.3 \\
\hline & V3 & $17.1 \pm 0.10$ & $67.0 \pm 2.0$ & $380 \pm 8$ & 2.5 \\
\hline & V4 & $21.1 \pm 0.15$ & $56.0 \pm 1.0$ & $230 \pm 9$ & 2.5 \\
\hline & V5 & $21.3 \pm 0.10$ & $53.0 \pm 2.0$ & $780 \pm 10$ & 1.7 \\
\hline
\end{tabular}


The concentration of Chl (Fig. 3) was high at sampling site D1 in Degurić Cave, and at V2 in Vernjikica Cave. On the rest of the sampling sites in both caves, similar values of this parameter were measured, except for V4 where the lowest concentration was determined.

In all biofilm samples from Degurić Cave, water content had the highest values, followed by the content of inorganic matter (Fig. 3). On the other side, inorganic matter had the highest values in all samples taken from Vernjikica Cave, except at V3 where water content was high. Organic matter in Degurić Cave had higher values at D1 and D5 compared to other sampling sites, and in Vernjikica Cave at V2 and V5. D5 and V5 are also sampling sites with higher measured light intensity.

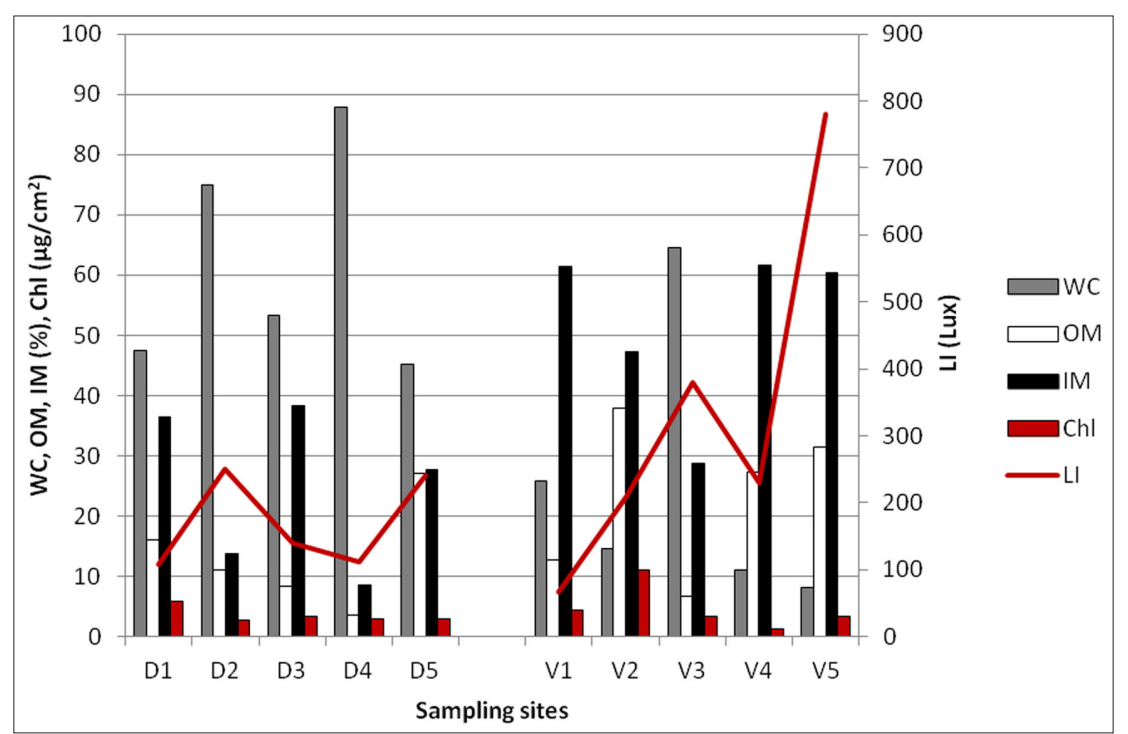

Fig. 3. The concentration of $\mathrm{Chl}$ in Degurić and Vernjikica caves, the content of inorganic (IM), organic matter (OM) and water content (WC) in biofilm samples - primary axis and light intensity (LI) - secondary Y-axis, from Degurić and Vernjikica caves. IM, OM, and WC are expressed in percentages for each biofilm sample.

The results of the quantitative analysis (the number of individuals, cells and biomass) of cyanobacteria and algae from biofilm samples of Degurić and Vernjikica caves are given in Tables 2 and 3.

The highest number of individuals in $1 \mathrm{mg}$ of biofilm sample at D1 is calculated for Desmococcus olivaceus, the highest number of cells for Leptolyngbya tenuis, and biomass for Chroococcus ercegovicii. Gloeobacter violaceus is accounted for the highest number of individuals and cells at D2. Biomass was quite low for almost all taxa, only Asterocapsa cf. purpurea had somewhat higher values. On the other side, this coccoid cyanobacterium was absolutely dominant at D3 when all three parameters were considered (the number of individuals, cells and biomass). Also, at D4, this taxon had the highest number of individuals, but the highest number of cells was assigned to Gloeocapsa nigrescens, and biomass to Nostoc commune. However, at D5, the highest biomass was calculated for Gloeocapsa nigrescens, while the highest number of individuals and cells was observed for species Chroococcus varius (Table 2).

At V1, Trebouxia sp. was dominant when the number of individuals and cells were considered, although the highest biomass was assigned to Orthoseira roseana. However, Trebouxia sp. was dominant at V2, and Desmococcus olivaceus at V4, considering all parameters. Sampling site V3 was characterized by the greatest number of individuals of taxon Gloeocapsa reicheltii, and the highest estimated biomass and number of cells for Aphanothece cf. bullosa. Chroococcidiopsis sp. had the highest number of individuals, Phormidium sp. 1 was the most abundant taxon regarding number of cells, while unidentified representative of Xanthophyta had the highest calculated biomass at V5 (Table 3).

The total number of individuals, cells and biomass in biofilm samples considering both caves is more precisely represented in Figure 4. The total number of individuals and cells, as well as biomass in Degurić Cave had the highest values at D1, and lowest at D2. In Vernjikica Cave, the highest number of individuals and cells were calculated for biofilm at V4, whereas the biomass had it's peak at V5.

It is worth mentioning that, as seen in Fig. 5a, total biomass showed a positive correlation with $\mathrm{Chl}$, content of organic matter in biofilm and light intensity, and it was negatively correlated with the distance from the entrance. When more detailed analysis that include relation of biomass separately for different algal and cyanobacterial groups along with other parameters was considered, it revealed the following: simple trichal Cyanobacteria, Bacillariophyta and Xanthophyta showed a positive correlation to light intensity and content of organic matter in biofilm, while coccoid and heterocytous Cyanobacteria, as well Chlorophyta were positively correlated to water content in biofilm, relative air humidity and distance from the entrance (Fig. 5b).

\section{DISCUSSION}

As mentioned, one of the ways for quantitative assessment of biofilm is the use of the sedimentation chambers. Welton et al. (2005) used the Helber's chamber, which is usually used for the counting of 


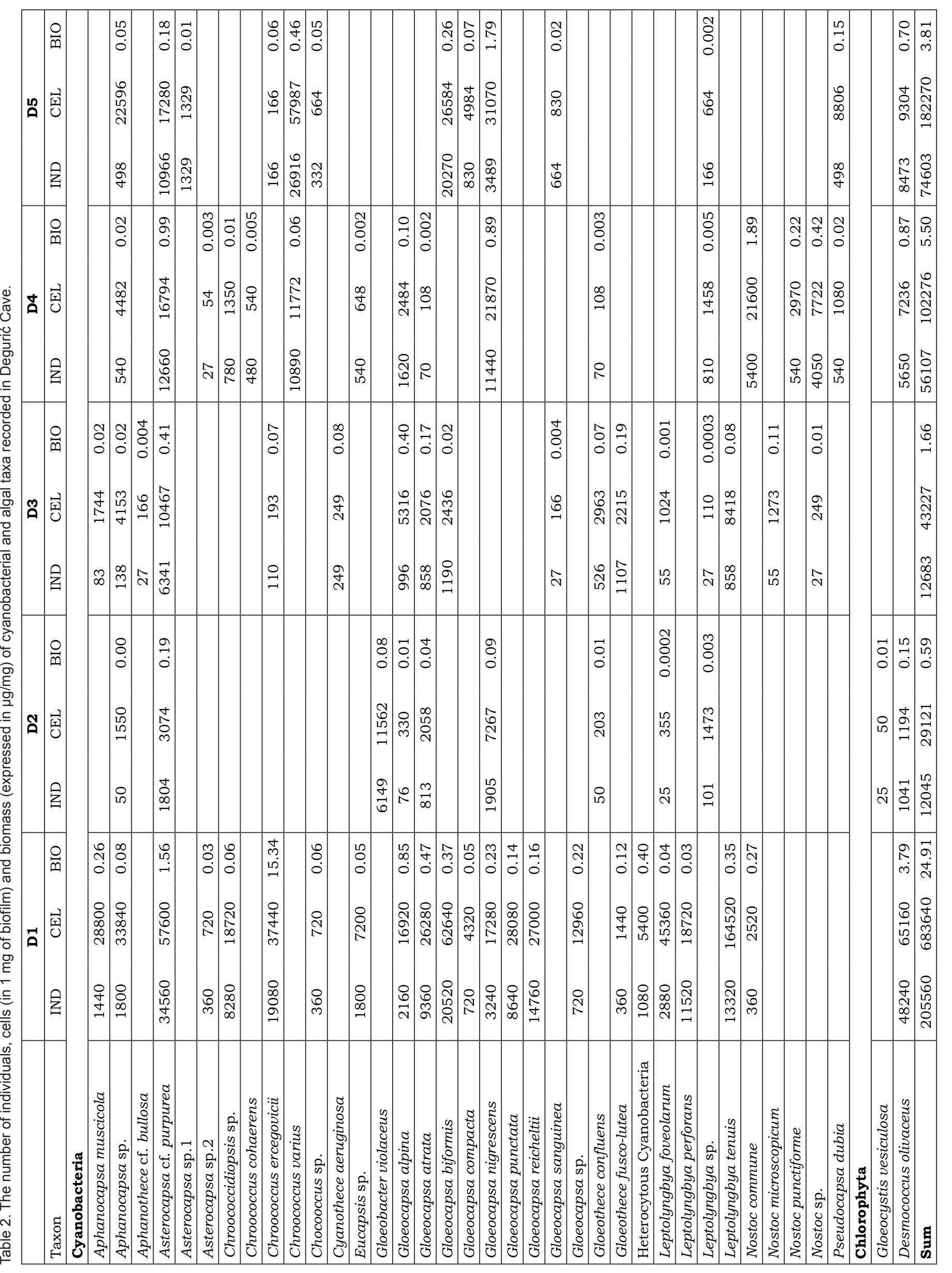




\begin{tabular}{|c|c|c|c|c|c|c|c|c|c|c|c|c|c|c|c|c|c|c|c|c|c|c|c|c|c|c|c|c|}
\hline & $\stackrel{\circ}{\stackrel{m}{*}}$ & & $\begin{array}{l}\mathrm{N} \\
\dot{0} \\
0\end{array}$ & & & $\begin{array}{c}0 \\
\dot{0} \\
0\end{array}$ & & & $\begin{array}{l}0 \\
0 \\
0 \\
0\end{array}$ & & & & & & & $\begin{array}{l}-1 \\
0 \\
0\end{array}$ & $\begin{array}{l}8 \\
\vdots \\
\vdots\end{array}$ & $\begin{array}{c}8 \\
: \\
0\end{array}$ & $\begin{array}{c}0 \\
\stackrel{0}{0} \\
0\end{array}$ & $\bar{\alpha}$ & & 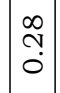 & & & $\begin{array}{l}\hat{y} \\
0\end{array}$ & & & 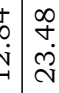 \\
\hline$\stackrel{10}{>}$ & 空 & & $\begin{array}{l}\text { bे } \\
\text { an }\end{array}$ & & & 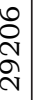 & & & $\begin{array}{l}\stackrel{0}{\mathcal{N}} \\
\underset{z}{z}\end{array}$ & & & & & & & 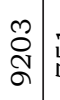 & $\overrightarrow{\mathrm{n}}$ & 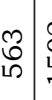 & 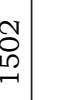 & $\mid \begin{array}{l}7 \\
1 \\
\infty \\
0 \\
1\end{array}$ & & 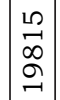 & & & 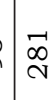 & & & 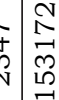 \\
\hline & 学 & & 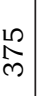 & & & $\begin{array}{l}0 \\
0 \\
0 \\
0 \\
-1\end{array}$ & & & $\begin{array}{c}\Delta \\
\infty \\
-1\end{array}$ & & & & & & & \begin{tabular}{l|l}
$o$ \\
\multirow{\sigma}{*}{}
\end{tabular} & ๙ & ๙ุ & ๙ & $\mid \begin{array}{c}\infty \\
\infty \\
\infty \\
0 \\
d\end{array}$ & & 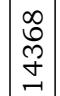 & & & $\left\{\begin{array}{l}\vec{\infty} \\
\sim\end{array}\right.$ & & & 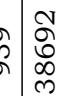 \\
\hline & $\stackrel{\circ}{\mathscr{m}}$ & & & & & : & & & & & & $\begin{array}{l}-1 \\
0 \\
0\end{array}$ & & & & & & & & & & $\begin{array}{l}\mathscr{m} \\
\stackrel{2}{i}\end{array}$ & & & & & & $\begin{array}{l}\text { \&े } \\
\text { i }\end{array}$ \\
\hline$\rangle^{+}$ & 完 & & & & & 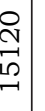 & & & & & & : & & & & & & & & & & $\begin{array}{l}\begin{array}{l}0 \\
+ \\
+ \\
+ \\
+\end{array}\end{array}$ & & & & & & 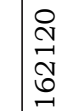 \\
\hline & $\gtreqless$ & & & & & 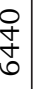 & & & & & & $\begin{array}{l}\stackrel{\infty}{\infty} \\
\stackrel{N}{N}\end{array}$ & & & & & & & & & & $\begin{array}{l}8 \\
0 \\
0 \\
0\end{array}$ & & & & & & 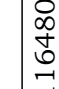 \\
\hline & $\stackrel{\circ}{\mathscr{m}}$ & & $\begin{array}{l}0 \\
0 \\
0 \\
0\end{array}$ & $\begin{array}{c}0 \\
0 \\
0\end{array}$ & $\begin{array}{l}8 \\
\\
\end{array}$ & $\begin{array}{l}0 \\
0 \\
0 \\
0\end{array}$ & $\begin{array}{l}0 \\
0 \\
0 \\
0\end{array}$ & $\begin{array}{l}-\overrightarrow{0} \\
\dot{0}\end{array}$ & & $\begin{array}{l}\overrightarrow{0} \\
\dot{0}\end{array}$ & $\begin{array}{l}0 \\
0 \\
0 \\
0\end{array}$ & & $\begin{array}{l}\begin{array}{l}t \\
0 \\
0\end{array}\end{array}$ & 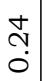 & $\mid \begin{array}{l}-1 \\
0 \\
0\end{array}$ & & & $\begin{array}{l}\overrightarrow{0} \\
\dot{0}\end{array}$ & a & & & $\begin{array}{l}7 \\
\stackrel{7}{0} \\
0\end{array}$ & & & & & & 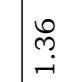 \\
\hline$\stackrel{m}{P}$ & 祍 & & $\begin{array}{c}0 \\
0 \\
\infty \\
= \\
=\end{array}$ & 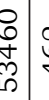 & 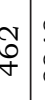 & 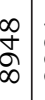 & $\begin{array}{l}\overrightarrow{\tilde{d}} \\
\stackrel{\mathrm{d}}{ }\end{array}$ & 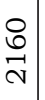 & & 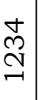 & 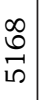 & & 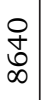 & $\begin{array}{l}\stackrel{2}{\mathbb{N}} \\
\mathbb{N} \\
\end{array}$ & $\mid \begin{array}{l}\infty \\
+ \\
\infty \\
\infty\end{array}$ & & & $\begin{array}{l}\vec{d} \\
\vec{N}\end{array}$ & 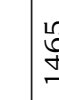 & & & 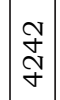 & & & & & & 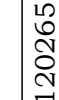 \\
\hline & 号 & & 号 & : & $\hat{N}$ & 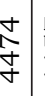 & 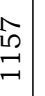 & 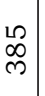 & & $\begin{array}{l}\stackrel{+}{10} \\
\stackrel{7}{7}\end{array}$ & $\begin{array}{l}\overrightarrow{\hat{N}} \\
\text { 岕 }\end{array}$ & & $\begin{array}{l}12 \\
0 \\
0 \\
0 \\
\cdots\end{array}$ & $\begin{array}{l}0 \\
0 \\
0 \\
0\end{array}$ & $\hat{\imath}$ & & & $\overrightarrow{\widetilde{N}}$ & $\hat{N}$ & & & 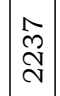 & & & & & & $\begin{array}{l}0 \\
\infty \\
\infty \\
m\end{array}$ \\
\hline & $\stackrel{\circ}{m}$ & & $\begin{array}{l}8 \\
0 \\
0\end{array}$ & & & & & & & & & & & & & $\begin{array}{l}8 \\
\vdots \\
0\end{array}$ & & $\begin{array}{l}8 \\
\vdots \\
0\end{array}$ & & & & $\mid \begin{array}{l}0 \\
0 \\
0\end{array}$ & $\begin{array}{l}\infty \\
\stackrel{0}{0} \\
\dot{+}\end{array}$ & & & $\begin{array}{l}\overrightarrow{0} \\
\dot{i}\end{array} \mid$ & & $\stackrel{0}{\stackrel{0}{6}}$ \\
\hline$\stackrel{N}{\mathbf{S}}$ & 完 & & 文 & & & & & & & & & & & & & $\stackrel{m}{\stackrel{m}{v}}$ & & ه্ & & & & 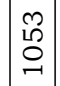 & 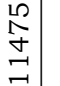 & & & $\stackrel{\wedge}{\wedge}$ & & $\begin{array}{l}\stackrel{2}{0} \\
0 \\
-1\end{array}$ \\
\hline & 害 & & $\hat{\sim}$ & & & & & & & & & & & & & $\stackrel{\wedge}{\wedge}$ & & $\widehat{\wedge}$ & & & & $\begin{array}{c}0 \\
\stackrel{\infty}{+}\end{array}$ & 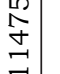 & & & $\widehat{\wedge}$ & & \begin{tabular}{l}
0 \\
0 \\
\multirow{2}{*}{}
\end{tabular} \\
\hline & $\stackrel{\varrho}{m}$ & & $\begin{array}{l}+ \\
0 \\
0\end{array}$ & & & $\begin{array}{l}0 \\
0 \\
0\end{array}$ & & & & & & & & & & $\begin{array}{l}8 \\
\vdots \\
0\end{array}$ & & & & & & & $\begin{array}{c}0 \\
\infty \\
0 \\
0\end{array}$ & & & $\begin{array}{l}0 \\
\stackrel{0}{2} \\
-i\end{array}$ & & $\begin{array}{l}\stackrel{a}{0} \\
\dot{i}\end{array}$ \\
\hline 5 & 窐 & & 号 & & & 令 & & & & & & & & & & $\begin{array}{l}0 \\
\infty \\
\infty\end{array}$ & & & & & & $\begin{array}{l}\infty \\
0 \\
1 \\
10\end{array}$ & 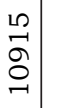 & & & $\stackrel{2}{\underset{\sim}{二}}$ & & $\begin{array}{l}\text { N } \\
\stackrel{N}{N}\end{array}$ \\
\hline & 宗 & & $\stackrel{\infty}{{ }^{\infty}}$ & & & 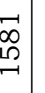 & & & & & & & & & & $\stackrel{\wedge}{\wedge}$ & & & & & & $\begin{array}{c}\hat{\alpha} \\
\stackrel{\sigma}{\sigma}\end{array}$ & \begin{tabular}{l}
$\mathbb{N}$ \\
\multirow{N}{0}{} \\
0
\end{tabular} & & & $\stackrel{\wedge}{\wedge}$ & & $\begin{array}{l}+ \\
0 \\
0 \\
0 \\
-1\end{array}$ \\
\hline & 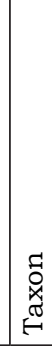 & 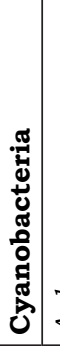 & 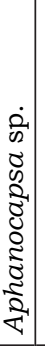 & 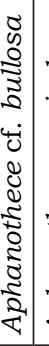 & 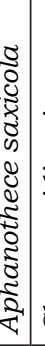 & 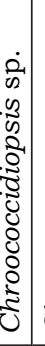 & 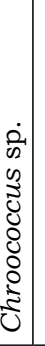 & 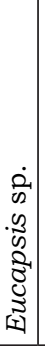 & 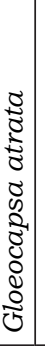 & 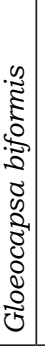 & 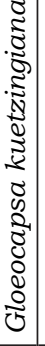 & 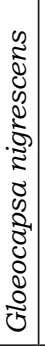 & 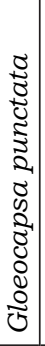 & 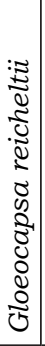 & 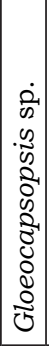 & 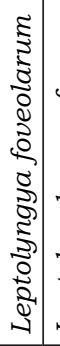 & 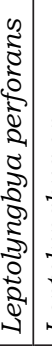 & 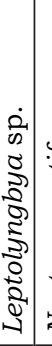 & 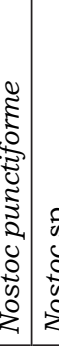 & 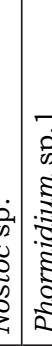 & 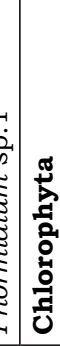 & 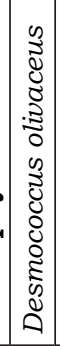 & 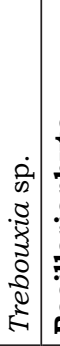 & 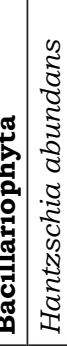 & 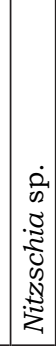 & 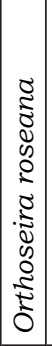 & 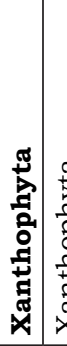 & 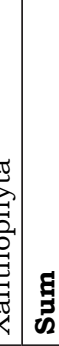 \\
\hline
\end{tabular}


bacteria (Collins \& Lyne, 2004). This technique is even more suitable for enumeration of algal cells or fungal spores, given that it can be performed at higher magnification. Furthermore, to assess the abundance of phototrophs from biofilm developed near thermal springs, Debnath et al. (2009) performed counting in Sedgwick-Rafter chamber. In their research, according to the abundance, descriptive characters were assigned - rare (less than 1\%), present (1-10\%) or very abundant (more than 30\%). Also, Bryanskaya et al. (2006) used the Goryaev chamber for the determination of the abundance and biomass. In this study, primary attempt was to implement Utermöhl method (1958), frequently used quantitative phytoplankton analysis as a standard method (EN 15204:2008). As suggested by Welton et al. (2005), biofilm samples of known mass were homogenized within certain water volume and the part of a solution was then sedimented in a counting chamber. However, biofilm dissolving was not entirely possible because of the adhesive properties of extracellular polymeric substances (EPS) that binds microorganisms cells together (Rossi \& De Philippis, 2015). Microorganism cells were also retained on the sedimentation chamber wall that caused the loss of sample. Counting of microorganisms was difficult not only due to glued cells, but also because of the presence of organic and inorganic particles that dissimulate the phototrophic microorganisms.

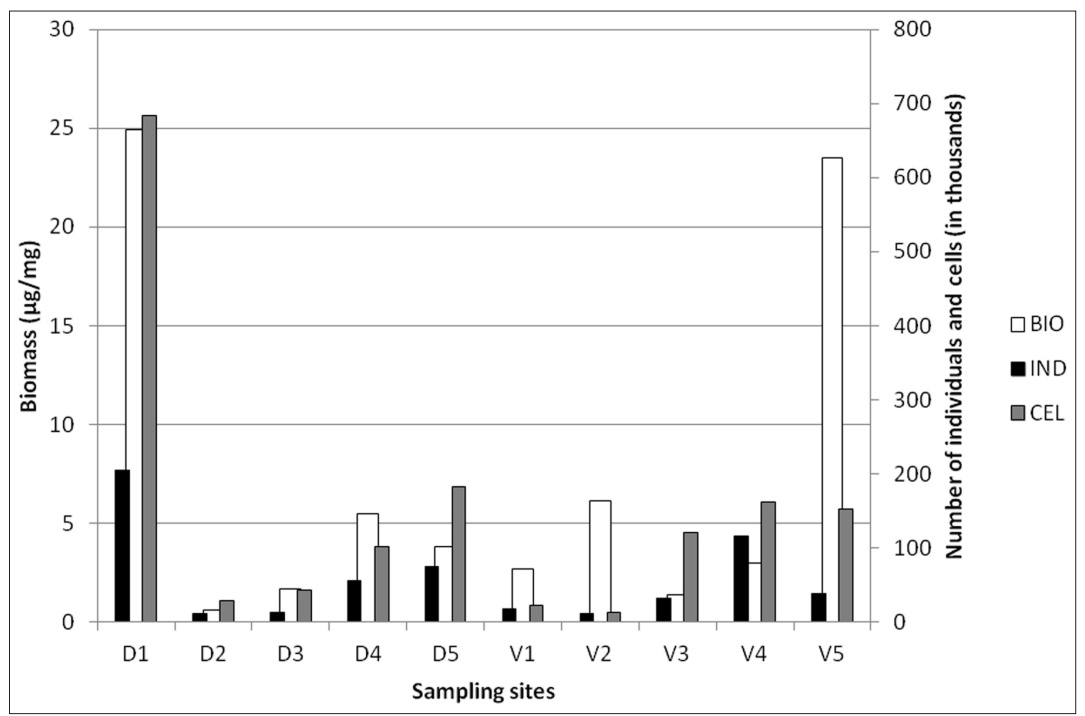

Fig. 4. The total number of individuals (IND), cells (CEL), and biomass (BIO) per sampling site in $1 \mathrm{mg}$ biofilm.

Ordinary slides for taxa identification slides are prepared in a simple way: part of a biofilm of the unknown weight is put on a slide, mixed with a drop of water or glycerol, homogenized as much as possible and observed under the microscope. Microscope slides prepared in such a manner are only suitable for taxa identification, but not for their counting as in many places on the slide, biofilm can be thick or cells of the microorganism can be glued together due to the EPS properties. Additionally, unknown biofilm mass is used during the preparation of the slides. In this regard, in order to count taxa and determine their biomass, a biofilm sample of a certain mass is needed; homogenization of biofilm has to be better performed, so microorganisms could be viewed more easily, and it is necessary to reduce "glue effect".

EPS can contain up to $95 \%$ of water and can be in a form of gel or in a colloidal form, which depends on chemical composition and temperature. Internal and external polysaccharides in the form of a gel stabilize macromolecular constituents of the cell and the cell structure, as well. In this regard, it is suggested that they form hydrogen bonds with proteins, membrane lipids and DNA. Due to the presence of uronic acids, EPS has sticky properties that binds cells to the substrate, as well as together (Potts et al., 1994; Stal, 2012). According to Pan et al. (2016), heating can be effectively used as one of the extraction physical methods and can cause hydrolysis of EPS and disrupt cells. The way of biofilm preparation in this study that included drying of a larger amount of biofilm (shortterm heating) which caused easier detachment of cells one from another, allowed biofilm to be equally distributed on the microscope slide. This served as a tool that enabled us easier counting and separation of biofilm constituents, which was one of the advantages. The counting of cells was harder only when organic and inorganic particles masked microorganisms. However, it is possible that biofilm preparation which includes short-term drying can alter the cells, slightly influencing their shape. Nevertheless, those changes are minor and within the limits of cell variability that naturally exists in samples: after rehydration (which occurred within a few minutes) they are not even easily observed under the microscope on the used magnification. The dehydration process in this study lasted for only one minute and was only temporary, not long lasting as e.g., many cyanobacteria and algae experience in nature habitat conditions after which they still recover very quickly. Cyanobacteria as the oldest phototrophic microorganisms can handle a wide spectrum of different extreme and unfavorable conditions and stresses among which is desiccation. Frequent and fast changing hydration/dehydration cycles are very common in all terrestrial/aerophytic cyanobacteria, and thanks to different mechanisms, these phototrophs respond almost immediately to such events. Many of them can reverse their 

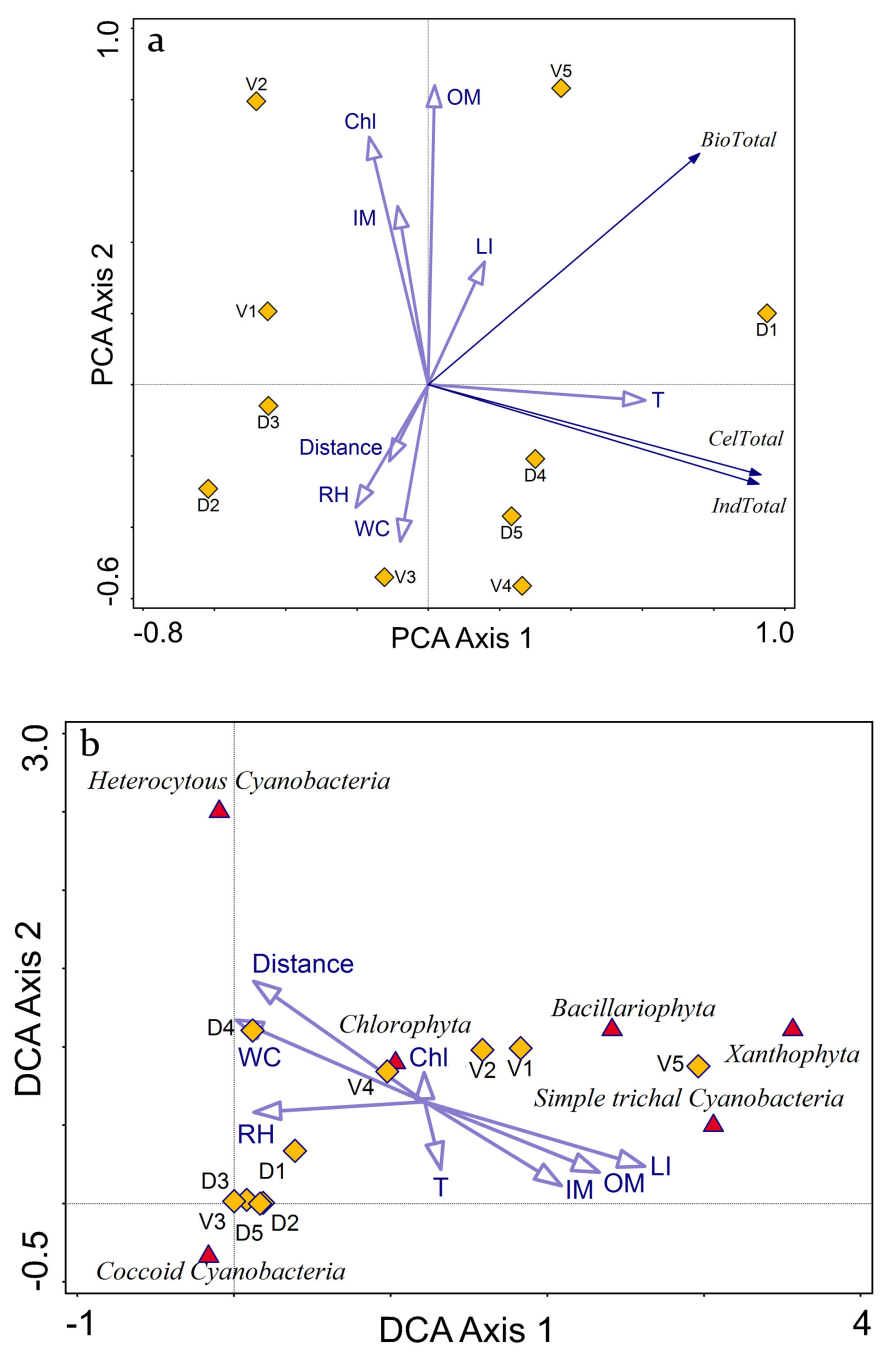

Fig. 5. a) PCA showing the relationship between ecological and biofilm parameters and the total biomass, number of cells and individuals; b) DCA showing the relationship between ecological and biofilm parameters and the biomass of every algal and cyanobacterial group separately. IM: the content of inorganic matter in biofilm; OM: the content of organic matter in biofilm; WC: the content of water in biofilm; Chl: chlorophyll; T: temperature; LI: light intensity;

$\mathrm{RH}$ : relative air humidity; V1 - V5: sampling sites in Vernjikica Cave; D1 - D2: sampling sites in Degurić Cave. IM, OM and, WC are represented per surface area $\left(\mathrm{mg} / \mathrm{cm}^{2}\right)$.

metabolism rapidly and hold back metabolic activity during dehydration (Potts, 1994). Cyanobacteria in desert crusts e.g. have the ability to resume metabolic activity upon rehydration within minutes (GarciaPichel \& Belnap, 1996; Potts, 1994). According to Gray et al. (2007), similar response of desiccated microalgae is observed in terrestrial, as well as in marine representatives (indicating that not only desert Cyanobacteria have those mechanisms). The rehydration response starts 1-2 min after adding water, while the reactivation of photosynthesis occurs after 13 min (Chennu et al., 2015). As mentioned, the EPS plays a role in desiccation tolerance, but some studies report on an intracellular mechanism that copes with this stressful factor (Shirkey et `al., 2000).

Regarding homogenization, it is observed that in nonhomogenized biofilm, non-representative part of the community can be taken for counting (e.g., part of a biofilm where few taxa dominate). Nevertheless, homogenization significantly reduce that error, as higher quantity of biofilm is mixed prior to separation of the subsample for microscopy.
In rare occasions, the same taxon in biofilm sample had the highest number of cells, individuals and the highest biomass. It happened only in cases where taxon was exclusively dominant in biofilm sample, such as Asterocapsa cf. purpurea at D3, Trebouxia sp. at V2 and Desmococcus olivaceus at V4. At sampling sites D1 and D4, different taxa had the highest values for the number of individuals, cells and biomass. For example, the highest number of individuals at D4 site had Asterocapsa cf. purpurea, unicellular cocoid cyanobacteria that often appears as unicellular, while in rare occasions stadiums containing more cells enveloped with the same sheath are present. On the other hand, Gloeocapsa nigrescens representatives mostly consisted of more cells enveloped with the same sheath, so the number of individuals was lower, in comparison to cell number. And finally, the highest biomass was recorded for Nostoc commune, a colonial cyanobacterium which formed very big colonies containing many cells. At V1, Trebouxia sp. was dominant when number of individuals and cells was observed, but the highest documented biomass was for diatom Orthoseira roseana due to the large volume of its cells.

At D1 where the highest biomass in the cave was determined, the higher diversity, water content in biofilm, as well as the highest Chl values were recorded. The high water content is the consequence of the presence of many coccoid cyanobacteria such as representatives of Gloeocapsa, Chroococcus and Aphanocapsa with very well developed EPS at this sampling site. On the other hand, at the sampling site with the highest determined biomass in Vernjikica cave, originating predominantly from one representative of Xanthophyta group, content of organic matter had rather high values.

As seen from Fig. 5a, Chl concentration and the total biomass were correlated and both showed a positive correlation with $\mathrm{OM}$ and $\mathrm{LI}$, but were not correlated with the distance from the entrance. According to this, Chl concentration and biomass gave us similar information when primary production was taken into consideration. This was interesting given that, while trying to correlate light with diversity of phototrophic microorganisms, the correlation was almost nonexistent. From this results the positive side of biomass determination for aerophytic canobacteria and algae in hypogenic habitat can be seen. The advantage in calculating biomass from biofilm sample is in the biomass estimation for every taxa or different groups of algae separately. As seen in Figure 5b, different groups of Cyanobacteria, as well as various algal taxa, showed correlation with different parameters. Firstly, the biomass of coccoid and heterocytous cyanobacteria showed a positive correlation with the content of water in biofilm. This is expected since representatives of these cyanobacterial groups have very well developed and thick sheaths. Furthermore, these groups also showed a correlation with the distance from the entrance, while simple trichal forms were negatively correlated with this parameter. According to some authors, coccoid forms of cyanobacteria are more tolerant to low light intensity and are found in the 
deeper part of the cave (Asencio \& Aboal, 2001; Mulec \& Kosi, 2008; Mulec et al., 2008; Martinez $\&$ Asencio, 2010), thus representing the dominant phototrophic microorganisms in these environments (Mulec et al., 2008). On the other hand, simple trichal forms are usually found on better illuminated places (Asencio \& Aboal, 2001; Martinez \& Asencio, 2010). Compared with Cyanobacteria, Bacillariophyta prefer more illuminated sites, which is concluded when the data about the vertical stratification of these groups in biofilm were taken into consideration (Roldán \& Hernández-Mariné, 2009). The primary production of green algae is higher at cave entrances (Piano et al., 2015) and diversity of Bacillariophyta is also connected with the proximity of the cave entrance (Falasco et al., 2014). As seen in Figure 5b, biomass of diatoms correlates with light.

Quantitative analysis enables us to precisely determine the dominant, subdominant and rare taxa in sample, their abundance and biomass. This is one of the main advantages compared to the determination of $\mathrm{Chl}$ content, because $\mathrm{Chl}$ can have similar values for samples where the difference in the dominance of certain algal groups can be observed. Thus, based on quantitative analysis, the influence of different environmental parameters and changes in community composition can be monitored in more detailed manner.

Many caves worldwide represent a natural phenomenon characterized with enormous beauty, aesthetic value, attractive cave formations, with many of them being historically and culturally significant. Due to all this they are very attractive sites for people and many of them have thus been adapted for tourist visits. However, the adaptation of a cave can have a negative impact on the cave ecosystem in general: changes in this fragile environment occur, leading to the disturbance of previously stabile microclimate conditions. By introducing light, caves become a suitable environment for the development of phototrophic microorganisms, cyanobacteria and algae. The development of these microorganisms on places around artificial lighting, the microorganism community called lampenflora, can alter rock substrate leading to the destruction of cave formations. Thus, lampenflora should be monitored, qualitatively and quantitatively assessed and treated. Physical and/or chemical treatments that involve the eradication of all phototrophic microorganisms should be used if needed (Gunn, 2004; Borderie at al., 2014; Hebelka, 2014). We believe that future research should focus on the study of physiology and deteriogenic capability of each taxon present in lampenflora. The determination of biomass for each taxon separately can help to better understand their ecology and physiology. The deteriogenic capability can differ from one taxa to another and possibly could be higher in those taxa that are not dominant, but subdominant or rare in the biofilm. Looking at the biofilm under a microscope, it can always be seen which taxa are dominant if cell numbers are taken into account. However, as it was demonstrated, biomass of taxa that have a lot of cells could be lower than those taxa that appear sporadically due to the larger cell dimensions.

\section{CONCLUSIONS}

Biofilm sampling was conducted in Degurić and Vernjikica caves in Western and Eastern Serbia. The distance from the entrance and ecological parameters (temperature $(\mathrm{T})$, relative humidity $(\mathrm{RH})$ and light intensity (LI)) were measured. Chlorophyll content, as well as biofilm parameters (water content (WC), organic $(\mathrm{OM})$ and inorganic (IM) matter) were also determined. The values of ecological parameters, except of LI, were similar at all sampling sites in one cave. The concentration of $\mathrm{Chl}$ was high at the sampling site D1 in Deguric Cave, and at V2 in Vernjikica Cave. Considering the biofilm parameters, the highest values were accounted for WC, followed by the IM, in the biofilm samples from Deguric Cave. In Vernjikica Cave, IM showed the highest values in all biofilm samples, except at V3 where WC was high. Higher values of OM in Degurić Cave were at D1 and D5, and in Vernjikica Cave at V2 and V5. Quantitative analyses of biofilms are rarely performed in scientific investigations. The counting of cyanobacteria and algae using sedimentation chambers (Utermöhl method) was not successful in this study. Microscope slides designed as described, that included biofilm dehydration and homogenization, followed by rehydration, were suitable and showed an advantage, when compared to the sedimentation method. At D1 where the highest total biomass in Deguric Cave was determined, high diversity, WC in biofilm (due to the presence of many coccoid Cyanobacteria), as well as the highest Chl values were also recorded. On the other hand, the highest determined biomass in Vernjikica Cave (at V5), which originated from one representative of Xanthophyta group, was at a sampling site where OM had high values. In general, the total biomass showed a positive correlation with Chl, OM, and LI, and it was negatively correlated with the distance from the entrance. When observed in more details, the biomass of simple trichal Cyanobacteria, Bacillariophyta, and Xanthophyta showed a positive correlation to LI and OM, while the biomass of coccoid and heterocytous Cyanobacteria, as well Chlorophyta, were positively correlated to $\mathrm{WC}, \mathrm{RH}$, and distance from the entrance.

\section{ACKNOWLEDGEMENTS}

The authors want to thank the anonymous reviewers for valuable suggestions and comments that significantly improved the clarity and quality of this manuscript. This research was supported by the Ministry of science and technological development, Republic of Serbia, projects no. 176018 and 176020.

\section{REFERENCES}

Abdelahad N., 1989 - On four Myxosarcina-like species (Cyanophyta) living in the Inferniglio Cave (Italy). Archiv für Hydrobiology Algological Studies, 54: 3-13. 
Albertano P., 2012 - Cyanobacterial biofilms in monuments and caves. In: Whitton B.A. (Ed.), Ecology of Cyanobacteria II: Their diversity in space and time. Springer, Dordrecht, 752 p. https://doi.org/10.1007/978-94-007-3855-3 11

Asencio A.D. \& Aboal M., 2001 - Biodeterioration of wall paintings in caves of Murcia (SE Spain) by epilithic and chasmoendolithic microalgae. Archiv fur Hydrobiologie. Supplementband: Algological Studies, 140: 131-142.

Borderie F., Tête N., Cailhol D., Alaoui-Sehmer L, Bousta F, Rieffel D., Aleya L. \& Alaoui-Sossé B., 2014 - Factors driving epilithic algal colonization in show caves and new insights into combating biofilm development with $U V-C$ treatments. Science of the Total Environment, 484: 43-52.

https://doi.org/10.1016/j.scitotenv.2014.03.043

Borderie F., Denis M., Barani E.A., Alaoui-Sossé B. \& Aleya L., 2016 - Microbial composition and ecological features of phototrophic biofilms proliferating in the Moidons Caves (France): investigation at the single-cell level. Environmental Science and Pollution Research, 23 (12): 12039-12049. https://doi.org/10.1007/s11356-016-6414-x

Breitig G. \& Tümpling W., 1982 - Ausgewählte Methoden der Wasseruntersuchung (Band 2). Biologische, mikrobiologische und toxikologische Methoden. Jena VEB Gustav Fischer Verlag, 580 p.

Bryanskaya A.V., Namsaraev Z.B., Kalashnikova O.M. \& Barkhutova D.D., 2006 - Biogeochemical processes in the algal-bacterial mats of the Urinskii alkaline hot spring. Microbiology, 75: 611-620. https://doi.org/10.1134/S0026261706050122

BS EN, 15708: 2009. Water quality. Guidance standard for the surveying, sampling and laboratory analysis of phytobenthos in shallow running water.

Chennu A., Grinham A., Polerecky L., de Beer D. \& Al-Najjar M.A.A., 2015 - Rapid Reactivation of Cyanobacterial Photosynthesis and Migration upon Rehydration of Desiccated Marine Microbial Mats. Frontiers in Microbiology, 6: 1472. https://doi.org/10.3389/fmicb.2015.01472

Czerwik-Marcinkowska J., Wojciechowska A. and Massalski A., 2015 - Biodiversity of limestone caves: aggregations of aerophytic algae and cyanobacteria in relation to site factors. Polish Journal of Ecology, 63: 481-499.

https://doi.org/10.3161/15052249PJE2015.63.4.002

Collins C.H. \& Lyne P.M., 2004 - Microbiological methods $\left(8^{\text {th }} E d\right)$. Butterworths, London, 465 p.

Debnath M., Mandal N.C. \& Ray S., 2009 - The study of cyanobacterial flora from geothermal springs of Bakreswar, West Bengal, India. Algae, 24: 185-193. https://doi.org/10.4490/ALGAE.2009.24.4.185

EN 15204: 2008. Water quality - Guidance standard on the enumeration of phytoplankton using inverted microscopy (Utermöhl technique).

https://www.iss.rs/standard/?natstandard document $\mathrm{id}=19282$

Falasco E., Ector L., Isaia M., Wetzel C.E., Hoffmann L. \& Bona F., 2014 - Diatom flora in subterranean ecosystems: a review. International Journal of Speleology, 43 (3): 231-251. https://doi.org/10.5038/1827-806X.43.3.1

Garbacki N., Ector L., Kostikov I. \& Hoffmann L., $1999-$ Contribution à l'étude de la flore des Grottes de Belgique. Belgian Journal of Botany, 132 (1): 43-76.

https://www.jstor.org/stable/20794440

Garcia-Pichel F. \& Belnap J., 1996 - Microenvironments and microscale productivity of cyanobacterial desert crusts. Journal of Phycology, 32 (5): 774-782.

https://doi.org/10.1111/j.0022-3646.1996.00774.x
Gray D.W., Lewis L.A. \& Cardon Z.G., 2007 Photosynthetic recovery following desiccation of desert green algae (Chlorophyta) and their aquatic relatives. Plant Cell Environment, 30: 1240-1255.

https://doi.org/10.1111/j.1365-3040.2007.01704.x

Gunn J., 2004 - Encyclopedia of caves and karst science. Taylor \& Francis, London, 902 p.

Hebelka J., 2014 - Methodology of lampenflora removal in caves accessible for tourists. The Cave Administration of the Czech Republic, Czech Republic.

Đurović P., 1998 - Speleološk atlas Srbije. Srpska akademija nauka i umetnosti, Beograd.

Hillebrand H., Dürselen C.D., Kirschtel D., Pollingher U. \& Zohary T., 1999 - Biovolume calculation for pelagic and benthic microalgae. Journal of Phycology, 35 (2): 403-424.

https://doi.org/10.1046/j.1529-8817.1999.3520403.x

Hofmann G., Werum M. \& Lange-Bertalot H., 2013 Diatomeen im Süßwasser - Benthos von Mitteleuropa. Bestimmungsflora Kieselalgen für die ökologische Praxis. Über 700 der häufigsten Arten und ihre Ökologie. Koeltz Scientific Books, Königstein.

ISO 10260: 1992. Water quality - Measurement of biochemical parameters Spectrometric determination of the chlorophyll-a concentration.

https://www.iso.org/standard/18300.html

Lamprinou V., Pantazidou A., Papadogiannaki G., Radea C. \& Economou-Amilli A., 2009 - Cyanobacteria and associated invertebrates in Leontari Cave, Attica (Greece). Fottea, 9: 155-164. https://doi.org/10.5507/fot.2009.014

John D.M., Whitton B.A. \& Brook A.J., 2003 - The freshwater algal flora of the British Isles: an identification guide to freshwater and terrestrial algae. Cambridge University Press, Cambridge, 702 p.

Komárek J., 2013 - Cyanoprokaryota 3. Teil/3rd Part: Heterocystous genera. In: Budel B., Gärtner G., Krienitz L. \& Schagerl M. (Eds.), Süsswasserflora von Mitteleuropa. Springer Spektrum, Heidelberg, 1130 p.

Komárek J. \& Anagnostidis K., 1998 - Cyanoprokariota. 1. Teil: Chroococcales. In: Ettl H., Gärtner G., Heynig H. \& Mollenhauer D. (Eds.), Süßwasserflora von Mitteleuropa. Spektrum Akademischer Verlag, Heidelberg, 548 p.

Komárek J. \& Anagnostidis K., 2005 - Cyanoprokaryota. 2. Teil: Oscillatoriales. In: Büdel B., Gärtner G., Krienitz L. \& Schagerl M. (Eds.), Süßwasserflora von Mitteleuropa. Spektrum Akademischer Verlag, Heidelberg, 759 p.

Komárek J. \& Fott B., 1983 - Chlorophyceae (Gr"unalgen). Ordnung: Chlorococcales. Das Phytoplankton d'es Süßwassers, Systematik und Biologie. In: Elster H.J. \& Ohle W. (Eds.), Die Binnengewässer XVI,, 7 (1). Stuttgart, Schweizerbart'sche Verlagsbuchhandlung, 1044 p.

Krieger W. \& Gerloff J., 1962 - Die gattung Cosmarium. Verlag Von J. Cramer, Weinheim, 112 p.

Martınez A. \& Asencio A.D., 2010 - Distribution of cyanobacteria at the Gelada Cave (Spain) by physical parameters. Journal of Cave and Karst Studies, 72: 11-20. https://doi.org/10.4311/jcks20091sc0082

Milanović S., 2012 - Speleologija i speleoronjenje u hidrogeologiji karsta. Rudarskogeološki fakultet, Beograd, 315 p.

http://www.karst.edu.rs/documents/pdf/biblioteka/ monografija/S-Milanovic-RGF 2012 Speleologija-ispeleoronjenje-u-hidrogeologiji-karsta.pdf

Mulec J. \& Kosi G., 2008 - Algae in the aerophytic habitat of Raĉiške Ponikve Cave (Slovenia). Natura Sloveniae, 10 (1): 39-49.

http://eprints.gozdis.si/id/eprint/1036 
Mulec J., Kosi G. \& Vrhovšek D., 2008 - Characterization of cave aerophytic algal communities and effects of irradiance levels on production of pigments. Journal of Cave and Karst Studies, 70 (1): 3-12.

Mulec J., Krištůfek V. \& Chroňákova A., 2012 Comparative microbial sampling from eutrophic caves in Slovenia and Slovakia using RIDA COUNT test kits. International Journal of Speleology, 41 (1): 1-8. https://doi.org/10.5038/1827-806X.41.1.1

Nagarkar S. \& Williams G.A., 1997 - Comparative techniques to quantify cyanobacteria dominated epilithic biofilms on tropical rocky shores. Marine Ecology Progress Series, 154: 281-291.

https://doi.org/10.3354/meps 154281

Pan M., Zhu L., Chen L., Qiu Y. \& Wang J., 2016 - Detection techniques for extracellular polymeric substances in biofilms: A review. BioResources, 11 (3): 8092-8115.

https://doi.org/10.15376/biores.11.3.8092-8115

Pápista E., Ács E. \& Böddi B., 2002 - Chlorophyll-a determination with ethanol - a critical test. Hydrobiologia, 485: 191-198.

https://doi.org/10.1023/A:1021329602685

Pentecost A. \& Zhaohui Z., 2001 - The distribution of plants in Scoska Cave, North Yorkshire, and their relationship to light intensity. International Journal of Speleology, 30 A (1-4): 27-37.

https://doi.org/10.5038/1827-806X.30.1.3

Pfendler S., Einhorn O., Karimi B., Bousta F., Cailhol D., Alaoui-Sosse L., Alaoui-Sosse B. \& Aleya L., 2017 $U V-C$ as an efficient means to combat biofilm formation in show caves: evidence from the La Glacière Cave (France) and laboratory experiments. Environmental Science and Pollution Research, 24 (31): 24611-24623. https://doi.org/10.1007/s11356-017-0143-7

Pfendler S., Karimi B., Maron P.-A., Ciadamidaro L., Valot B., Bousta F., Alaoui-Sosse L., Alaoui-Sosse B. \& Aleya L., 2018a - Biofilm biodiversity in French and Swiss show caves using the metabarcoding approach: First data. Science of the Total Environment, 615: 1207-1217.

https://doi.org/10.1016/j.scitotenv.2017.10.054

Pfendler S., Alaoui-Sossé B., Alaoui-Sossé L., Bousta F. \& Aleya L., 2018 - Effects of UV-C radiation on Chlorella vulgaris, a biofilm-forming alga. Journal of Applied Phycology, 30 (3): 1607-1616.

https://doi.org/10.1007/s10811-017-1380-3

Piano E., Bona F., Falasco E., La Morgia V., Badino G. \& Isaia M., 2015 - Environmental drivers of phototrophic biofilms in an Alpine show cave (SWItalian Alps). Science of the Total Environment, 536: 1007-1018. https://doi.org/10.1016/j.scitotenv.2015.05.089

Popović S., Subakov Simić G., Stupar M., Unković N., Predojević D., Jovanović J. \& Ljaljević Grbić M., 2015a - Cyanobacteria, algae and microfungi present in biofilm from Božana Cave (Serbia). International Journal of Speleology, 44 (2): 141-149.

https://doi.org/10.5038/1827-806X.44.2.4

Popović S., Subakov Simić G., Stupar M., Unković N., Predojević D., Blagojević A. \& Ljaljević Grbić M., 2015b - Cyanobacteria, algae and microfungi from Degurić Cave, west Serbia. $6^{\text {th }}$ Balkan Botanical Congress, September 14-18, University Campus Rijeka, Croatia, $100 \mathrm{p}$.

Popović S., Subakov Simić G., Korać A., Golić I. \& Komárek J., 2016a - Nephrococcus serbicus, a new coccoid cyanobacterial species from Božana Cave, Serbia. Phytotaxa, 289 (2): 135-146.

https://doi.org/10.11646/phytotaxa.289.2.3
Popović S., Jovanović J., Predojević D., Trbojević I., Blagojević A. \& Subakov Simić G., 2016b-Phototrophic microorganisms in biofilm samples from Vernjika Cave, Serbia. Geophysical Research Abstracts, 18: EGU201616064.

Popović S., Jovanović J., Predojević D., Trbojević I., Blagojević A., Jakovljević O. \& Subakov Simić G., 2016c - Cyanobacteria and algae from biofilms: the comparison of phototrophic microorganism community from cave entrance and lampenflora - Lazareva Cave, Serbia. $5^{\text {th }}$ Congress of Ecologists of Macedonia, Macedonia (Ohrid) 19-22, October, 125 p.

Popović S., Subakov simić G., Stupar M., Unković N., Krunić O., Savić N. \& Ljaljević Grbić M., 2017a - Cave biofilms: characterization of phototrophic cyanobacteria and algae and chemotrophic fungi from three caves in Serbia. Journal of Cave and Karst Studies, 79 (1): 10-23. https://doi.org/10.4311/2016MB0124

Popović S., Jovanović J., Blagojević A., Trbojević I., Predojević D., Nikolić N., Vidović M. \& Subakov Simić G., 2017b - Diversity of epilithic and endolithic cyanobacteria and green algae at the entrance of two caves in Serbia. $11^{\text {th }}$ International Phycological Congress, Szczecin, Poland, p. 13.

Potts M., 1994 - Desiccation tolerance of prokaryotes. Microbiological Review, 58: 755-805.

https://mmbr.asm.org/content/58/4/755

Pouliĉková A. \& Hašler P., 2007 - Aerophytic diatoms from caves in central Moravia (Czech Republic). Preslia, 79: 185-204.

Prieto B., Silva B. \& Lantes O., 2004 - Biofilm quantification on stone surfaces: comparison of various methods. Science of the Total Environment, 333: 1-7. https://doi.org/10.1016/j.scitotenv.2004.05.003

Rajczy M., Buczkó K. \& Komáromy P., 1986 Contributions to the flora of the Hungarian caves I. Flora of the entrances of the caves Lök-völgyi-barlany and Szeleta-barlany. Studia Botanica Hungarica, 9: 79-88.

Roldán M. \& Hernández-Mariné M., 2009 - Exploring the secrets of the threedimensional architecture of phototrophic biofilms in caves. International Journal of Speleology, 38 (1): 41-53. https://doi.org/10.5038/1827-806X.38.1.5

Rossi F. \& De Philippis R., 2015 - Role of Cyanobacterial exopolysaccharides in phototrophic biofilms and in complex microbial mats. Life, 5 (2): 1218-1238. https://doi.org/10.3390/life5021218

Sallstedt T., Ivarsson M., Lundberg J., Sjöberg R., Ramón J. \& Romani V., 2014 - Speleothem and biofilm formation in a granite/dolerite cave, Northern Sweden. International Journal of Speleology, 43 (3): 305-313. https://doi.org/10.5038/1827-806X.43.3.7

Sant'Anna C., Branco L. \& Silva S., 1991 - A new species of Gloeothece (Cyanophyceae, Microcystaceae) from São Paulo State, Brazil. Algological Studies, 92: 1-5.

Selvi B. \& Altuner Z., 2007 - Algae of Ballica Cave (Tokat-Turkey). International Journal of Natural and Engineering Sciences, 1 (3): 99-103.

Sgier L., Freimann R., Zupanic A. \& Kroll A., 2016 Flow cytometry combined with viSNE for the analysis of microbial biofilms and detection of microplastics. Nature Communications, 7: 11587.

https://doi.org/10.1038/ncomms 11587

Shirkey B., Kovarcik D.P., Wright D.J., Wilmoth G., Prickett T.F., Helm R.F., Gregory E.M. \& Potts M., 2000 - Active Fe-containing superoxide dismutase and abundant sodF mRNA in Nostoc commune (Cyanobacteria) after years of desiccation. Journal of Bacteriology 182: 189-197. https://doi.org/10.1128/JB.182.1.189-197.2000 
Smith T. \& Olson R., 2007 - A taxonomic survey of Lamp Flora (Algae and Cyanobacteria) in electrically lit passages within Mammoth Cave National Park, Kentuky. International Journal of Speleology, 36 (2): 105-114. https://doi.org/10.5038/1827-806X.36.2.6

Stal L.J., 2012 - Cyanobacterial Mats and Stromatolites. In: Whitton B.A. (Ed.), Ecology of Cyanobacteria II: Their diversity in space and time. Springer Science, Dordrecht, $752 \mathrm{p}$.

https://doi.org/10.1007/978-94-007-3855-3_4

Starmach K., 1972 - Chlorophyta III. Zielenice nitkowate: Ulotrichales, Ulvales, Prasiolales, Sphaeropleales, Cladophorales, Trentepohliales, Sipholales, Dichotomosiphonales. Warszawa and Krakow, Panstwowe Wyadwnictwo Naukowe, series Flora slodkowodna Polski 10, 750 p.

Sun J. and Liu D., 2003 - Geometric models for calculating cell biovolume and surface area for phytoplankton. Journal of Plankton Research, 25 (11): 1331-1346. https://doi.org/10.1093/plankt/fbg096

Ter Braak C.J.F. \& Šmilauer P., 2012 - Canoco Reference Manual and User's Guide: Software for Ordination, version 5.O. Ithaca, USA, Microcomputer Power, 496 p.

Tofilovska S., Wetzel C.E., Ector L. \& Levkov Z., 2014 - Observation on Achnanthes Bory sensu stricto (Bacillariophyceae) from subaerial habitats in
Macedonia and comparison with the type material of $A$. coarctata (Brébisson ex W. Smith) Grunow A. coarctata var. sinaensis Hustedt and A. intermedia Kützing. Fottea, 14 (1): 15-42.

https://doi.org/10.5507/fot.2014.002

Utermöhl H., 1958 - Zur vervolkmmung der quantitativen phytoplankton methodik. Verhandlungen der Internationalen Vereinigung für Theoretische und Angewandte. Limnologie, 9: 1-38.

Vinogradova O.N., Nevo E. \& Wasser S.P., 2009 - Algae of the Sefunum Cave (Israel): species diversity affected by light, humidity and rock stresses. International Journal on Algae, 11: 99-116.

https://doi.org/10.1615/InterJAlgae.v11.i2.10

Welton R.G., Ribas Silva M., Gaylarde Ch., Herrera L.K., Anleo X., De Belie N. \& Modry S., 2005 - Techniques applied to the study of microbial impact on building matherials. Matherials and Structures, 38 (10): 883-893. https://doi.org/10.1007/BF02482255

Wilson C., Lukowicz R., Merchant S., Valquier-Flynn H., Caballero J., Sandoval J., Okuom M., Huber C., Durham Brooks T., Wilson E., Clement B., Wentworth C.D. \& Holmes A.E., 2017 - Quantitative and qualitative assessment methods for biofilm growth: a mini-review. Research \& Reviews: Journal of Engineering and Technology, 6 (4): 1-25. 